\title{
Lesson Study in Vocational Education and Training
}

\author{
The status quo in four European countries
}

\author{
Claudia Mewald ${ }^{1}$, Michaela Tscherne ${ }^{1}$, Sabine Zenz ${ }^{1}$, Eszter Bükki², János Györi², James \\ Calleja $^{3}$, Michael Buhagiar ${ }^{3}$, Michelle Attard Tonna ${ }^{3}$, Therese Camilleri ${ }^{3}$, Anne Khaled ${ }^{4}$, \\ Marloes van der Meer ${ }^{4}$
}

https://doi.org/10.53349/resource.2021.i16.a998

\section{Abstract}

This paper introduces the ERASMUS+ project LS4VET, which aims to develop a Lesson Study model for the VET sector with the goal to encourage innovation and change in vocational education by creating an open-online course to support collaborative professionalism for VET educators. The status quo of Lesson Study in the four partner countries Austria, Hungary, Malta, and the Netherlands is described and an outlook on the development of a Lesson Study model for VET is given.

\section{Lesson Study in der Berufsbildung}

\section{Der Status quo in vier Europäischen Ländern}

Zusammenfassung

In diesem Beitrag wird das ERASMUS+-Projekt LS4VET vorgestellt, welches das Ziel verfolgt, ein Lesson StudyModell für den Berufsbildungssektor zu entwickeln und einen offenen Online-Kurse für Berufsbildner*innen zu entwickeln, der Innovation und Wandel in der Berufsbildung durch Lesson Study und kollaborativen Professionalismus initiieren soll. Der Status quo der Lesson Study in den vier Partnerländern (Österreich, Ungarn, Malta, Niederlande) wird beschrieben und durch einen Ausblick auf die Entwicklung eines Lesson Study Modells für die Berufsbildung ergänzt.

\author{
Keywords: \\ Lesson Study \\ Vocational Education and Training (VET) \\ Collaborative Professionalism
}

\author{
Schlüsselwörter: \\ Lesson Study \\ Berufsbildung \\ Kollaborativer Professionalismus
}

\section{Introduction}

Although vocational education and training (VET) have been discussed widely among the member states of the European Union (EU) for many years, the implementation of VET in the various countries is still very diverse. Despite the members' commitment to providing possibilities for VET students to enter higher and further education, various VET systems still maintain pathways which make transition difficult while others have created possibilities for progression. More recent long-term structural changes and trends within VET suggest that national qualification frameworks in most EU member states will develop further towards a diversity of vocational qualifications ranging from European Qualification Framework (EQF) level 1 to 8 by 2030 (Markowitsch \& Helfer, 2019). Moreover, changing professional needs on the job-market and increasingly diverse learner groups call for innovative and adaptive approaches to teaching and learning in VET. However, research in this context suggests that although pedagogical change is often advocated in VET, it has not or not successfully been implemented across Europe (CEDEFOP, 2015). It thus seems important to introduce effective and sustainable continuous professional development (CPD) in vocation-specific as well as pedagogicalmethodological areas.

\footnotetext{
${ }^{1}$ Pädagogische Hochschule Niederösterreich, Mühlgasse 67, 2500 Baden, Austria Corresponding author E-mail:claudia.mewald@ph-noe.ac.at

2 Eötvös Loránd University Institute of Intercultural Psychology and Education, Hungary

${ }^{3}$ Faculty of Education, University of Malta \& Institute of Tourism Studies

${ }^{4}$ University of Applied Sciences Utrecht \& Stichting Landstede, Netherlands
} 
This paper introduces a European project aiming at innovation and change in VET through Lesson Study (LS), a model of teacher professional development based on teacher collaboration and focusing on the improvement of student learning through developing VET teachers' methodological competence. The goals of this an ERASMUS+ key action 2 project (see Appendix 1), called Teachers' Collaboration through Lesson Study for Improving the Quality of Vocational Education and Training (LS4VET) ${ }^{5}$, emphasise the assumption that teachers working collaboratively will develop a high level of professional capital and help their schools outperform institutions where teachers work in isolation (Leana, 2011; Hargreaves \& Fullan, 2012). LS teams are communities of practice which create teacher learning based on professional collaboration (Ainley \& Carstens, 2018; Bolam et al., 2005; Dudley, 2012; Dudley, 2015; Schleicher, 2020) and the outlook of creating sustainable collaborative professionalism (Hargreaves \& O'Connor, 2018). The LS method, however, has only been applied sporadically in vocational schools before (Mewald et al., 2021). Therefore, LS4VET aims to adapt the LS methodology for the VET sector to achieve sustainable LS practice in this field creating positive impact on the quality of teaching and learning in schools that will apply the method. The LS approach pursues a bottom-up development, where CPD is created by and with teachers in job-embedded processes in authentic teaching and learning scenarios. Its genuine goal is to improve student learning through teachers investigating new teaching methods and working collaboratively in the design, implementation, evaluation, and reflection of research lessons over an extended period of time.

The adaptation of the LS approach for VET is achieved through close collaboration of teacher educators, VET educators, and their schools in four partner countries: Austria, Hungary, Malta, and the Netherlands. The project involves the development and piloting of a theoretical framework, the LS4VET Model, an e-learning course, a handbook, and mentoring for VET educators, who will get to know, adapt, and evaluate LS in VET schools.

\section{Theoretical considerations on LS in VET}

LS is a model of teacher professional development which originated in Japan over 100 years ago. The components of the Japanese LS model, which became well known all over the world after 1999, include research and preparation, goal setting and lesson planning in small groups, the implementation of a research lesson, observations of student learning by peers and other experts, reflection and analytic discussions of observations as well as student feedback and data, revision of the research lesson, repetition of the same, discussion and reflection, reporting including suggestions to improve the lesson further, as well as goal setting for additional cycle(s) (Stigler \& Hiebert, 1999). In this process, Japanese LS teams rely on the support of knowledgeable others (Takahashi, 2013) who encourage the thoeretical grounding of the research lesson.

In its global spread, several adaptions to the LS model were made in different countries. For example, the UK developed its own LS model and several different models emerged in the USA (see Table 1, Appendix 2). While the Japanese model of LS is predominantly used in general education, its international spread has taken LS into different systems, social-cultural contexts, and sectors of education. This includes the implementation of LS in higher education, initial teacher education, teacher induction, or CPD (Larssen et al., 2018; Wood et al., 2019, Mewald \& Rauscher, 2019; Mewald, 2020). Moreover, with the rapid development of information and communications technology, online LS has been developed. However, LS genuinely remains a classroom activity and its online implementation faces various challenges, especially in connection with teacher collaboration and student observation.

Skott and Møller (2019) describe four adaptation approaches of LS: In the first approach, they observe direct adaptations of authentic LS to different contexts while the second approach concentrates on important cultureindependent conditions for successful adaptation. The third one focuses on aspects that may affect the adaptation in considering the cultural differences between Japan and the adapting countries. The last approach is sensitive to the conflicts and power relations in teachers' work when it comes to the adaptation of LS.

The LS4VET project mainly applies the third and fourth approach according to Skott and Møller (2019) in the adaptation of its LS model. In three pre-studies, the culture- and context-specific conditions for a meaningful adaptation of the Japanese LS model were identified (Bükki \& Györi, 2021; Calleja et al. 2021; Mewald et al., 2021). These studies provided insight about previous and current experiences of using LS in VET and in other sectors of education in the four partner countries. Moreover, they identified the individual and organizational conditions relevant for the adaptation of existing LS models to VET contexts. These included the description of the specifications of VET teachers' professional working conditions and their educational needs.

${ }^{5}$ https://Is4vet.itstudy.hu/ 
In conclusion, three important aspects for the adaptation of the model were identified:

1. The roles of the students, knowledgeable others, and LS facilitators need to be described carefully to create a model that is sensitive to the needs of LS participants in the VET sector.

2. Although the variety in the organisation of teaching and learning across the LS4VET partner countries is considerable, the common core that is most relevant in the development of the LS4VET model is the emphasis on establishing strong links of LS with vocational domains.

3. An adaptation of LS to VET needs to consider the heterogeneity of the teaching staff as well as that of the students.

The LS4VET model must thus be flexible to be applicable within different systems within the partner countries and beyond. Moreover, it needs to be adaptive to the needs of heterogeneous learner groups across Europe. As a result, the LS4VET project aims to adapt the method of LS to the VET context based on its findings from the pre-studies, in addition to considering the partners' national models (see Table 2, Appendix 3) with special attention to the phases of LS, the support through knowledgeable others and/or LS facilitators, and the inclusion of the learners' voice. Finally, relevant findings from research into LS will be included.

\section{Education, VET, and LS in the LS4VET partner countries}

This section deals with LS in the four partner countries and its role in education and VET. Data supporting four country reports was collected through an online survey with 48 respondents in early December 2020. The goal of this survey was research on LS in the four countries to provide initial information for the development of a LS model and a curriculum for a LS e-learning course for VET educators. The survey comprised 48 questions which referred to LS in general, and LS in VET education specifically. Moreover, a qualitative interview study with the goal to explore the organisational and individual conditions of conducting Lesson Study in VET schools and another on-line survey about professional development needs of VET teachers were carried out in the partner and associated schools of this project.

\subsection{Education, VET, and LS in Austria}

The structure of the Austrian educational system is based on age and relates to different talents, career goals as well as lifelong tasks. Thus, it ranges from elementary to vocational education up to tertiary education (BMBWF, n.d.). In Austria, learners have to complete at least nine years of education and pursue secondary education or take up an apprenticeship after finishing compulsory education until they are 18 years old.

At the beginning of their education, pupils attend four years of primary school, followed by four years in middle or lower academic secondary schools (5th to 8th grade). Academic secondary school also comprises a four-year upper-level (9th to 12th grade) and concludes with a standardised school leaving exam, which qualifies for university studies (BMBWF, n.d.). The final school year of compulsory schooling after grade 8 may be the first year at upper secondary level or pre-vocational education followed by an apprenticeship.

At upper secondary level, pupils choose between pre-vocational, vocational, or general education programmes. $68 \%$ of the learners choose vocational education paths (Dornmayr \& Nowak, 2020; Hoeckel, 2010). In the context of vocational education, they may decide between dual vocational education for apprentices, intermediate vocational education (1-4 years), or colleges for higher vocational education (5 years).

Around $40 \%$ of the learners enter apprenticeship (Mohr, 2021) and attend compulsory part-time vocational schools, which last between 2-4 years. The dual system of vocational education in Austria combines parallel training on the job and in vocational schools. Approximately $20 \%$ of the apprenticeship takes place in vocational schools where the focus is on profession-specific theoretical and practical training and profession-specific foreign language training supplemented by general education, which takes up approximately $35 \%$ of the school time (BMDW, 2020). Apprentices take final apprenticeship examinations conducted by the Chamber of Economy Austria (WKÖ) with certificates allocated to EQF Level 4 (WKO NÖ, 2021).

Around $27 \%$ of the learners on a VET pathway attend colleges for higher vocational education, which last for five years and offer higher vocational training in different specialist areas, general education, and a standardised school leaving exam as well as a VET diploma. Thus, graduates acquire a double qualification (Hoeckel, 2010) and are entitled to exercise legally regulated apprenticeship occupations according to the Austrian Commercial Code and enter tertiary education (BMBWF, 2020). 
According to Hoeckel (2020), the teacher workforce in VET education is divided into three types: practical trainers in school workshops, teachers of theoretical aspects of vocational subjects, and teachers of general education. Teachers in vocational schools for apprentices and industry-based teachers for vocational subjects in colleges for higher vocational education are prepared to teach based on educational training and professional experience of at least three years. Many VET schools employ teachers who work part-time in industry to keep professionally up to date (Hoeckel, 2010). Unlike teachers for general education, industry-based teachers do not require a degree in education for employment.

University colleges of teacher education offer bachelor programmes (EQF Level 6) to address the professional learning needs of teachers for vocational subjects in VET schools and colleges: Specialist Additional Studies for career changers are part-time teacher education which qualify to teach in the field of secondary vocational education and the secondary level in vocational education qualifies to teach in dual vocational education or as practical trainers in school workshops (BMBWF, 2020; PH NÖ, 2021a). A master's degree is optional for some fields. However, to be entitled to teach subject-related theory in VET schools or colleges, teachers need to provide master-level qualification in the relevant specialised field (Hoeckel, 2010). The University College of Teacher Education in Lower Austria (PH NÖ) offers a four-semester master's degree programme in inclusive education called Secondary Education/Vocational Education - Inclusive Education (MEd). Participants develop general and pedagogical, vocational subject-specific, didactic, inclusive, intercultural, personal, and social competences (PH NÖ, 2021b).

\subsubsection{LS in Austria}

Austrian Lesson Studies encompass pre-study research, collaborative planning, plans for research lessons, observation plans, post-lesson interviews or surveys, case students, reflection meetings or post lesson debriefings, knowledgeable others or LS facilitators, and LS reports or dissemination. While collaborative planning, plans for research lessons, and reflection meetings or post lesson debriefings are always part of LS, pre-study research, observations, post-lesson interviews or surveys, and case students are not always included. Equally, the collaboration with knowledgeable others or LS facilitators and the dissemination of LS through open research lessons or reports are rather often part of LS in Austria but not yet fully established (Mewald, 2020).

Austrian LS teams usually plan research lessons for one to more than three hours and 2-3 cycles are usually carried out within one semester with each cycle lasting for about one month. However, time spent on LS varies depending on participants and goals of the study. "Time is never recorded with a stopwatch - but teachers report about long preparation and reflection meetings" (translated from comments to question $\mathrm{nr} .10$ ).

LS is most frequently implemented in Austrian primary, lower secondary, upper secondary, and tertiary institutions, while VET schools and higher (vocational) educational institutes only sometimes implement LS. It has a history of 10 years in Austria and in the beginning, primary and lower secondary schools engaged in LS. Later, upper secondary schools joined. Moreover, LS has been implemented from the very beginning in Austrian initial teacher education (ITE) and CPD. The main goals for teachers to engage in LS are to improve their teaching and their pupils' learning quality (focus on their own classroom) and to learn from other teachers in professional learning communities (focus on collaboration with other teachers). To research effective methods for teaching, in particular a focus on topics or content, is also considered a very important goal. The feedback about the relevance of research being a goal in LS ranges from very to not important according to the online survey. Moreover, acquiring qualification in higher education could be a very important goal to engage in LS for Austrian teachers.

The participation of learners in LS is considered very important in Austria. All age groups, even young learners (6-12 years old), are actively involved in LS through planning, as participating learners, through giving feedback about learning during and after research lessons, through participating in reflection or debriefing as well as in the variation of the research lesson. Of course, the degree and nature of participation depends on the age group and the goals of the LS.

While some institutions carry out LS without funding, LS is mostly part of CPD, which is organised through the university colleges of teacher education and teachers receive refund for travelling. Moreover, LS holds towards their obligation to take part in in-service. The results from the online survey suggest that improved status would be an additional incentive to participate in LS for Austrian teachers.

Austrian school principals support LS in that they facilitate its implementation. They mostly understand LS as an important contribution to teacher professionalisation, provide organisational support, and take active roles in embedding LS in the School Quality Assurance programme of their schools. 
LS is not yet implemented on a regular basis in Austrian VET schools or teacher education, but it has been carried out since 2015. According to the survey, VET teachers active in LS currently participate about twice a year in LS. VET-LS teams are mostly mixed teams of 4-6 subject and practice teachers, knowledgeable others or LS facilitators are always involved. Austrian VET teachers usually plan research lessons for 5 hours and they typically implement 2-3 cycles.

In VET, teachers primarily aim at the improvement of teaching and their professionalisation if they engage in LS. There are no institutional incentives for VET teachers to engage in LS and no general obligations either. Participating in LS is rather based on word-of-mouth recommendation within the profession. VET teachers participate in LS because they want to engage in professional exchange and collect LS experience to enhance their experience in good teaching practice. Recent developments in Austria are the inclusion of LS in VET teacher education curricula and the implementation of on-line courses in PCD.

At the beginning of 2021, teachers, heads of formal teacher teams and school leaders of our VET partner schools in the four partner countries were interviewed to identify relevant factors for the adoption of the LS methodology in VET with the primary objective to collect data on the organisational and individual conditions related to teamwork and LS in order to assist planning the piloting of the model of LS4VET within this project (Bükki \& Győri, 2021)

The Austrian interviewees confirm a friendly and open working atmosphere and appreciative and supportive team culture at the associated school, the HTL Wr. Neustadt. The school leader provides adequate support for collaboration and considers teamwork very important. Consequently, the informal communication processes enable collaboration of teams and rich collaboration among teachers of the same subjects. Although there is no co-teaching or joint research, teachers team-teach in optional Robotics classes and VET teachers collaboratively develop teaching materials if no textbooks are available. Occasionally, there are joint training courses. Annual foci support the vision of innovativeness and link departments. Overall, there is a strong emphasis on student performance rather than observation of colleagues.

Classes are organised in double units of 100 minutes and 50-minutes units in workshops or laboratories. Project work, most commonly in cooperation with external partner organisations, are implemented in the 4th and 5th grades, allowing the students to gain practical experience. Besides project-based instruction there are theory lessons employing lecture-style and practice lessons.

None of the Austrian interviewees has ever participated in LS. However, the approach is not completely new for them: They have some basic knowledge of it. Regarding the pilot, interdisciplinary teams of 4-6 people including two teachers in the field of general education are recommended. Moreover, involving a knowledgeable other should be considered to allow outside views. The topics suggested by the respondents are German or English language studies, student motivation, abstract and analytical processes, programming, and assessment.

The interviews revealed workload as a main challenge for any additional CPD. In addition, different time schedules are considered a problem in organising collaboration. In the school, cooperation between departments is difficult due to short breaks, spatial separation, and different timetables. To organise LS, meetings in the late afternoon or on Saturdays are recommended. As far as digital teaching and learning are concerned, the teachers are well equipped and have been used to working on-line since the first Covid lockdowns. Thus, online LS is considered viable, though monitoring and giving feedback might be a challenge.

\subsection{Education, VET, and LS in Hungary}

Education in Hungary is compulsory from age 3 to age 16. Following compulsory kindergarten education, children participate in 4 years of primary and 4 years of lower secondary education (in single structure eight-year primary school programmes, though there are also highly competitive eight- and six-year general education programmes with integrated lower and upper secondary education starting at age 10 or 12). Upon completion, students can choose between a general education and two VET tracks in upper secondary education (a third one is available for learners with special educational needs). The general education track (called grammar school) typically lasts 4 years and awards the standardised secondary school leaving exam certificate, which is required for continuing studies at post-secondary or tertiary level.

Vocational education and training in Hungary are thus offered to students from age 14 in two main pathways at upper and post-secondary level. Vocational programmes called higher education VET are also available in higher education, but since 2013 these are not considered part of VET and are regulated by different legislation. The structure of VET, its legal framework, curricula, and even the names of the main VET pathways have been repeatedly changed in the past decade (Bükki, 2019). These near-permanent reforms aimed to increase the 
prestige and attractiveness as well as the quality of VET, which are still generally lower compared to general education. While there are some highly popular, competitive schools in the VET pathway which spans upper and post-secondary education, lower-level VET programmes attract mostly low-achieving students, often from a disadvantaged social background, with poor basic skills and motivation. Dropout rates are high, and student achievement is very low in these programmes (Fehérvári, 2014; Hermann et al., 2020). The latest structural reforms were introduced from schoolyear 2020/2021. VET awarding vocations listed in the Register of Vocations, available exclusively in VET schools (so-called vocational education), and VET awarding more flexibly updated vocational qualifications offered in VET schools as well as training companies (so-called vocational training) are now differentiated.

Students enter VET upon completing the eight years of primary school at age 14 (schooling is compulsory until age 16). Around $40 \%$ continue studies in general education at upper secondary level (in grammar schools), the others enter VET (Bükki, 2019): Around a quarter of students enter three-year upper secondary level skilled workers' training, currently called vocational school programmes. These offer general education and sectoral VET in the first year (grade 9), followed by two years of vocational training, and award an EQF level 4 qualification that qualifies one to perform a vocation, but not to enter tertiary level education. Students need to complete an additional two-year general education programme (offered in all such schools since 2016) to obtain the standardised secondary school leaving exam certificate to be able to continue studies in higher education. Around $60 \%$ of learners hold an apprenticeship contract and thus receive their practical training at a workplace. The share of practical training is $60-70 \%$ of the vocational curriculum, depending on the vocation studied. Around a third of students enter five-year VET programmes, currently called technical school, that span upper secondary (first four years) and post-secondary levels (year 13) and combine general and vocational education to award dual qualifications: a 'vocation' as well as the standardized secondary school leaving exam certificate. Only a fourth of these learners hold an apprenticeship contract and the majority receive their practical training at the school, the share of which varies from $20 \%$ to $70 \%$, depending on the vocation studied. Post-secondary VET is also available to those with the secondary school certificate but no prior vocational training (grammar school graduates).

Since general education and in-school vocational practice are both included in the curriculum of each VET programme type, three different profiles of teachers work in Hungarian VET schools, who are characterised by different qualification requirements and professional background (Bükki, 2019): Teachers of general (academic) subjects must hold a subject-relevant teacher qualification (since the introduction of the Bologna system, this is available only at master level). These teachers might have previously been teaching in primary schools or in grammar schools. Vocational teachers teach vocational subjects (they can teach both theory and practice) and until recently, although they could start teaching with only a higher education degree, they had to obtain a master level vocational teacher qualification within 5 years. Therefore, most vocational teachers do hold a pedagogical qualification. Expert interviews in the context of this study and a previous one suggest that a substantial proportion of vocational teachers are second-career teachers, who start their pre-service teacher education only after they have started teaching (Bükki, 2018). Current qualification requirements permit teaching with only a subject-relevant tertiary level degree, professional experience is not required, but highly appreciated.

Vocational trainers, who supervise vocational practice in school workshops (i.e., they teach practical subjects), can be employed with a bachelor level vocational instructor qualification or even with only a secondary school certificate, a relevant vocational qualification, and at least five years of professional experience.

VET teacher qualifications can currently be obtained in three types of higher education programmes, though the majority of learners study in the shorter programmes and in evening education, while already teaching in a VET school (Bükki, 2019): 4+1-year undivided (long) university programmes, which include subject-specific training (minimum 160 credits), a teacher training module (50 credits) and a one-year-long final external school teaching practice (40 credits); or four-semester master programmes with one semester long external teaching practice (the duration of these programmes can be reduced to three semesters by recognizing previous teaching experience); or two-semester master programmes providing pedagogical training, available to those who already hold a master diploma in the professional field.

Vocational instructor training is offered in seven-term bachelor level programmes in three areas (business, technology and agriculture) and various specialisations. They consist of subject-specific training, pedagogical studies (including psychology) and practical training, the latter includes a teaching practice and a 12 week-long external vocational practice.

Following the most recent reforms that completely separated VET from the system of so-called public education (which refers to education for all - from kindergarten to post-secondary education), all teachers of 
VET schools became employees instead of their previous public servant status, and they are no longer part of the teacher career system. In-service training remained mandatory for them, currently they must participate in a further training programme of at least 60 hours every four years. These are now offered in more VET-specific topics, mainly in general pedagogy and methodology.

Due to the unattractive working conditions (low salary, low prestige, decreasing teacher autonomy, and a highly challenging job), it is getting increasingly difficult to hire vocational teachers/trainers. The VET teacher population is aging, and the share of part-time instructors is growing (Információs és Technológiai Minisztérium, 2018).

\subsubsection{LS in Hungary}

Following the first publications in English on Japanese jogyou kenkyuu in the 1990s (Lewis \& Tsuchida, 1998; Stigler \& Hiebert, 1999), the first pieces of information on LS appeared in Hungarian educational literature during the 2000s. However, the practical dissemination and implementation of the method is a very slow evolutionary process in the country - we can say, LS is still taking its first steps in Hungary.

János Gordon Győri, one of the authors of the present study and the consortium leader of the LS4VET Erasmus+ project, already took part on the very first WALS conference in 2007 in Hong Kong, where he gave a presentation on the structural and cultural aspects of the method's adaptation in Hungary (Gordon Győri, 2007a). In the very same year, he published the first introductory article on LS in Hungarian (Gordon Győri, 2007b), and soon after he introduced Lesson and Learning Study methods in detail in a Hungarian monograph (Gordon Győri, 2009).

As the results of his activity, many of the ITE students learn about LS in Hungary nowadays, although this is usually only a sub-topic of certain ITE courses. ITE students did not and do not gain much real experience about LS in Hungary, because teacher educators are not really familiar with LS in the practice. However, as the microteaching method has been widespread in teacher education in Hungary, already since the 1970s, some teacher educators try to combine micro-teaching and LS in ITE, building on similar international initiatives (Bencze, 2018). The LS method also appears in some Hungarian in-service teacher training programmes, but only a few training programmes address it in a separate course. For example, the in-service teacher education programme of KÖVI (Dutch-Hungarian School of Educational Leadership, University of Szeged), has been offering a LS course for Hungarian teachers and future educational leaders since the beginning of 2010.

While the method is already relatively widely known in Hungary among those who are involved in teacher education, and thus also known by the younger generations of teachers in practice today, the method is still rarely used in practice. Only two major developments can be mentioned in this respect.

The first Hungarian LS project has been developed in a small Hungarian city, Eger, in the academic year of 2014-2015, and the first Hungarian Learning Study project was run in Miskolc in 2015-2016 (Czók \& Győri, 2015). In Eger, a small group of primary school teachers in a school - which was attached to Eszterházy Károly University (at that time: Eszterházy Károly College) - as a school for field practice for student teachers - the LS team teachers chose the topic of Supporting self-study and highlighting the essence of a text in class 4 (10 year-old pupils), and with the support of an external expert they prepared and ran a research lesson on a non-fiction text type. In their work they followed the steps of the classical (Japanese) LS. In Miskolc, in a VET school, a small team of volunteer teachers from the English department worked out the exercise plan for a bilingual group in class 9 and, based on different situational language teaching methods, they prepared and ran a research lesson with their students on Simple Past Tense Questions. The teachers of this project conceptualized their project as Learning Study, but in reality they used a kind of combination of Lesson and Learning Study.

According to the teachers' opinion, both projects were successful. The primary school teachers emphasized how important it was that they could pay attention to very small, micro segments of their teaching process in a class, and they could analyse these small segments very carefully for a long time. The VET school teachers emphasized that for them to learn a lot on Lesson and on Learning Study, and to read the relevant educational literature on their English teaching topic was important and useful. The collaborative work was a very memorable experience for the Eger team as well as for the Miskolc group of teachers. In both schools, the school principals were very supportive. In Eger, even the LS team members were appointed by the principal of the school as the first experimental team in LS in Hungary. In this sense, the Eger experiment had a top-down start. However, later the teachers, who were carefully prepared by the Eszterházy College staff how to run a lesson study project, could work autonomously. They could choose the topic, their own timetable, and everything else. In the VET school, the process was very much the opposite: The teachers, who already knew LS from the Hungarian 
literature, asked for the principal's support to start a LS project. After they got this institutional permission, they started their project by themselves, very autonomously (however, with the professional support by János Gordon Győri). So, it was a classical bottom-up activity of the teachers, and the very first VET LS run anytime in Hungary.

However, neither the Eger nor the Miskolc project had a continuation in these schools, so these projects remained one-and-only occasions in these teachers' professional lives and in the history of their institutions. This draws even more attention to the importance of sustainability of LS in educational institutions. Also, although LS was run in a VET institution in Miskolc, it was not a VET-specific LS, since all the teachers of the team were teachers of a typical academic - and not a VET-specific - subject, namely English as a Foreign Language.

As it was already mentioned, LS is not widespread method in Hungarian education. The Hungarian LS4VET project members conceptualize the VET-specific LS will serve as a kind of Trojan horse in Hungarian education, and they hope it will open the doors for a widespread use of LS in Hungarian education.

In the LS4VET project, data was collected from the Hungarian project partners through an online survey $(\mathrm{N}=30)$ as well as interviews with leaders and teachers at the Hungarian partner VET school. Additionally, the Hungarian expert partners collected data in a nationwide non-representative online survey, based on an extended and adapted version of the two questionnaires used in the LS4VET project (Mewald et al., 2021; Calleja et al., 2021).

Four Hungarian project partner teachers, who took the online survey, had implemented LS at their institution, six teachers reported about LS in in-service teacher training programmes, and five said LS had been implemented in projects (Mewald et al., 2021). The LSs they had participated in typically included pre-study research, planning meetings, research lesson plans and reflection meetings, but only two respondents indicated it involved case students and LS reports. Most LS teams planned their research lessons for about one unit and the LSs took one cycle. Students were typically part of planning the $L S$ and gave feedback after the research lesson, only one person responded that students had also participated in reflection meetings.

Interviews at the Hungarian partner school were conducted with the principal and vice-principal, a head of department, a VET teacher, as well as with six teachers of different subjects, professional background, and teaching experience in a focus group discussion (Bükki \& Győri, 2021). None of the interviewees had ever participated in a Lesson Study and only three had some knowledge of it. This school is rather advanced in teacher collaboration and innovation, the majority of teachers are open to new ideas and have a strong internal motivation to learn and improve their teaching. School leaders are aware of the importance of and fully support teacher collaboration. Apart from its positive school climate and supporting leadership, the specific profile of this VET school (IT) also yields some atypical features relevant to teacher professional development, such as the strong collaboration of teachers of vocational theoretical and practical subjects (in fact, most vocational teachers in this school teach both), the involvement of IT practitioners, and VET teachers' strong motivation to follow the industry developments, which are even faster here than in some other vocational fields. When asked about how they would imagine LS being implemented in their school, most of them perceived homogeneous LS teams (the team members teach the same subject), or teams made up of teachers from at most two departments, combining, for example, an IT area and a general subject, more viable. Indeed, some of the previous voluntary projects in the school were based on such collaboration. They thought teachers could be encouraged to do a LS by appealing to their strong internal motivation, but they would have to see that LS was meaningful and useful for them.

In a nationwide online survey conducted by ELTE and iTStudy in June 2021, VET school teachers were asked about their prior experiences with LS based on the LS4VET country fiche questionnaire (Mewald et al., 2021), as well as their ideas about the feasibility of implementing the different LS components in their own school in a newly designed question. 268 teachers completed the online questionnaire, our cleaned database includes data from 257 teachers: $55.9 \%$ teach general subjects and $44.1 \%$ vocational subjects (mostly both theory and practice). Most work in schools providing VET in tourism and catering (26.2\%), machinery (11.7\%), IT and telecommunication (11.3\%), or economy and management (8.2\%). Half of our respondents have never heard of LS. Nearly a third $(28,5 \%)$ have only read about it. One in five $(19.9 \%)$ learnt about LS in their pre- or in-service training at a university, $5.5 \%$ more in a further training organized by other providers. There was no statistically significant difference between general subject and vocational teachers as to whether and where they had learnt about LS. Only three respondents had ever participated in LS but only two answered our questions about their LS experiences. One participated in LS at a primary school funded by the school maintainer, the other at a teacher further training in a project focusing on the integration of Roma students. Their LSs, both implemented several years ago, consisted of one cycle, one only one occasion, the other of three weeks. The students were not actively involved. 
In this survey, teachers were also asked how feasible they considered implementing the various components of a LS in their own school. Most respondents believe most LS components could be easily or relatively easily accomplished (see Figure 1, Appendix 4). The vast majority do not see any difficulties in identifying a research topic and researching it. Most think, however, that LS that involves more than one cycle could be accomplished only with difficulty. The organisation of the research lesson itself does not seem unproblematic to them. Forming LS teams is among the components that appear to pose most difficulties. Respondents believe it is easier to form LS teams from teachers of the same subject than of different subjects. They also think that involving students in choosing the research topic or discussing the research lesson can be accomplished relatively easily. In an open question format, teachers were also asked about what they would see as the most important difficulties related to each LS component and how these could be solved. Based on a preliminary analysis of their replies, they mentioned the low number of teachers teaching the same subject (10.6\%), lack of time, much workload (10.6\%), and negative collegial relations or attitude of colleagues (5.0\%). Of all the listed LS components, there was only one regarding which we found a statistically significant difference in the opinion of teachers by profile: General subject teachers ( $N=98, M=2.46$ ) see it more difficult to involve students in the planning of the research lesson than vocational teachers $(N=80, M=2.76$; based on the analysis of variance, ANOVA: $F(1,177)=6.211, p=0.014$; $\mathrm{h} 2=0.034)$. This might be explained by the different attitudes and motivation of students towards learning general and vocational subjects in Hungarian VET schools (see Appendix 4).

\subsection{Education, VET, and LS in Malta}

As a member of the European Union (EU), Malta's education system is influenced by EU policies on education, namely Education \& Training 2020 (2009), Bruges Communiqué (2010) and Rethinking Education Communiqué (2012). In reaction to these EU policy documents, the Ministry for Education (MFED, 2014a, 2014b, 2015) embarked on a policy reform in Malta that culminated in a number of policy documents, namely Framework for the Education Strategy for Malta 2014-2024 (2014), Strategic Plan for the Prevention of Early School Leaving in Malta (2014), and National Vocational Education and Training Policy (2015). The academic year 2011-2012 was an important milestone for VET in Malta, as it marked the beginning of a two-year pilot project that introduced four vocational subjects at MQF Level 3 within the mainstream secondary school curriculum. The four vocational subject areas were: Engineering, Hospitality, Information Technology, and Health and Social Care. At that time, more than $50 \%$ of students who continued their education at post-secondary level were opting for vocational institutions. To sustain further this growing trend, the number of VET subjects that secondary school students could choose from in Year 9 (i.e., 13-year-old) was raised from four to nine by the beginning of the 2019-2020 academic year.

The introduction of nine vocational subjects within the secondary school mainstream curriculum created a lacuna of trained teachers within the field of vocational education. The increasing number of secondary schools offering vocational subjects and the increasing number of students selecting vocational options further heightened the necessity for professional teacher development in the field of vocational education.

In light of these emerging realities, the Faculty of Education at the University of Malta launched two master's programmes (MQF Level 7) to address the professional learning needs of teachers in vocational subjects.

Master in Teaching and Learning (MTL) in Vocational Education is an entry-level qualification for pre-service teachers. Those who will follow this course will specialise in pedagogical content knowledge (after having obtained a first-cycle degree in content knowledge), in educational context knowledge, and in educational research and inquiry. The focus on this MTL ensures a combination of subject content knowledge with industry experience through a combination of pedagogy and practical study units.

Master of Arts (MA) in Vocational Education currently offered in four subject areas: Hospitality, Health and Social Care, Engineering and Fashion \& Textiles. This course, offered to in-service teachers of traditional academic subjects seeking to transition into teaching VET subjects in secondary schools, is designed to facilitate teachers' transition into the field of vocational pedagogy. It, hence, aims to equip teachers with subject knowledge, skills, and competences. An important feature of this MA course is that it connects subject content knowledge through 160 hours of industry experience, thus allowing teachers to transition to the world of work and familiarise themselves with the challenges of the industrial sector. The 2018-2019 cohort of 24 MA students spent 80 hours of industry-based experience in a range of industrial placements, namely: five-star hotels; manufacturing factories; fashion and textiles, design and retail outlets; homes for the elderly and persons with disability; childcare centres; engineering industries; household design and retail outlets. 
In Malta, LS was first introduced with a group of mathematics teachers in 2017. Following this experience, Collaborative Lesson Study Malta (CLeStuM) ${ }^{6}$ was set up within the Faculty of Education, University of Malta. James Calleja leads CLeStuM in collaboration with Michelle Attard Tonna and Michael Buhagiar. CLeStuM works to support schools in Malta to learn about, initiate and sustain collaborative LSs. Over the past four years, CLeStuM participated in 15 LSs across primary, secondary and post-secondary schools.

\section{CLeStuM aims to}

- provide professional development for teachers and school leadership teams on the lesson study process,

- facilitate lesson study meetings with teachers,

- observe and provide constructive feedback on lesson studies,

- conduct research on lesson studies,

- $\quad$ organise events in Malta to disseminate collaborative lesson studies, and

- $\quad$ participate in conferences and meetings to present research findings.

CLeStuM also offers a website which includes numerous free and downloadable resources that teachers may use. These resources include articles, website links, videos, sample lesson plans, observation sheets, and lesson study reports.

When conducting LS, the CLeStuM team members usually work with a small group of teachers (2 to 6 teachers) or individual teachers. One of the CLeStuM team members usually acts as a LS facilitator. This role involves leading teachers through the LS process and helping them in their collaborative work on their research lesson. Within the process of LS, CLeStuM also seeks to involve a member of the school leadership team and a subject expert. For example, for a VET LS, a VET expert would be invited to act as a knowledgeable other and to provide the LS participants with feedback about the research lesson planning phase. This expert would also be involved in observing the research lesson and then in the post-lesson discussion.

\subsubsection{The Institute of Tourism Studies and Lesson Study}

The Institute of Tourism Studies (ITS), which was established in 1987, is Malta's main tourism and hospitality educational institution. This state-owned institution enjoys a measure of independence and autonomy, granted that it operates within the established academic parameters. It is governed in fact by a Board of Studies that is chaired by the Head of School who acts as Chief Operating Officer. The other members of this board are the Heads of Departments, the academic coordinators, and the lecturers' and students' representatives. ITS offers a vast selection of programmes and teaching is held on a campus that is equipped with well-resourced labs and lecture rooms. This ensures that students receive both theoretical and practical education of the highest quality. Courses at ITS start from MQF Level 2 and go up to MQF Level 7. Students can move vertically in their chosen area of study from one level to the next, but not horizontally from one programme of studies to another. ITS has presently circa 700 full-time students and this number goes up to more than 1200 when part-time students are included. At present, 90 students have special needs, and they receive ongoing support from six learning coaches.

As part of the LS4VET project, insights on the professional operations within ITS were obtained through indepth semi-structured interviews with the head of school, a head of department and a lecturer. The three interviewees were identified for participation by ITS. It emerged from the three interviews that there is a certain level of open-mindedness among lecturers at ITS with regards to the introduction of new teaching methods and professional development initiatives, including LS. However, this trend is reportedly stronger among lecturers teaching theory-based courses than lecturers teaching practice-based courses. The three interviewees suggested that the lower interest among the practice-based lecturers was due to the fact that their courses normally follow well-established sequences of teaching and learning that are very specific, something that makes it harder to introduce new practices.

According to the head of school, professional development (PD) is one of the hallmarks of this educational institution. ITS organises, in fact, in-house PD programmes for lecturers that, although mandatory, allow flexibility on the part of lecturers to decide when they need to engage in PD and what they require from their PD. Taking a needs-based approach, PD is thus organised on the basis of a professional growth conversation that

\footnotetext{
${ }^{6}$ https://www.clestum.eu/
} 
the Head of School, with the assistance of his collaborators, holds at the end of each academic year with all lecturers at ITS.

Another issue that emerged from the interviews was related to the generally transversal form of collaboration that exists among the teaching staff at ITS. This collaboration is characterised by groups of lecturers working together on a particular issue that is of a common interest to all of them, usually irrespective of their subject of specialization or department. This transversal collaboration is most common during the planning phases of specific courses as part of developing new or updating existing programmes of studies. However, the formal and informal professional discussions among ITS teaching staff are usually limited to guiding individual lecturers to design specific course components, plan specific lectures, and conduct corresponding student assessments. In line with this largely individualistic approach when it comes to actual planning, teaching and assessment, the practice of collaborative teaching is practically new at ITS. Interview data indicate in fact that lecturers at ITS do not feel comfortable sharing their work with others and there is still no culture of peer observation among teaching staff.

The three interviewees were not aware of what LS was and what it would entail. By the end of the interview, however, they had all acquired through the interviewer a basic understanding of LS in relation to teacher education. Asked to identify possible areas that could be addressed through LS at ITS, the Head of School suggested that a LS could help to improve the teaching of subjects that incorporate theoretical rather than practical components. On this part, the lecturer suggested a LS that would target pedagogical rather than content issues. The rationale behind this suggestion was that while ITS lecturers are recognised content specialists, there seems to be a lot of divergence and lack of deep knowledge in matters related to teaching approaches. The issues of adequate time allocation and professional incentives (e.g., recognizing lesson study as a PD activity that counts for career progression) were mentioned by both the lecturer and the Head of Department. Reflecting a general positive disposition towards LS, the three interviewees concurred that by engaging in LS, lecturers would experience professional growth, as they would be better equipped to identify areas in need of professional development and also improve through their participation the quality of their lectures. With regard to the ongoing covid-19 pandemic, the Head of School offered reassurances that ITS and its staff are well-prepared to engage profitably in an online LS experience.

\subsection{LS in the Netherlands}

In the Netherlands, LS has been firmly established for more than ten years. In the beginning, secondary and primary education used LS, special needs schools as well as higher education institutions are currently piloting LS in the Netherlands. The National Consortium LSNL ${ }^{7}$ holds on the Dutch Lesson Study model. They offer training courses for LS facilitators and organize LS conferences and publish in professional and scientific journals about their LS approach.

The Dutch Lesson Study cycle starts with an orientation on the theme and determining the goal through, for example, literature study, inventory of good practices, exploration of the practical theory of participating teachers or of expert teachers. In the second phase, a research lesson is designed, followed by the third phase, during which the research lesson is conducted by a team member; other team members observe and collect data on teaching and learning through observations, interviews, questionnaires, test analyses, etc. In the fourth stage, the lesson is discussed, and the collected data is collectively analysed and the adaptations to the lesson design are discussed. The lesson is adjusted if necessary and performed again in the fifth phase. During the last phase, what has been learned by students and teachers is determined and the results are shared.

In the Netherlands, all LSs encompass pre-study research, collaborative planning, plans for research lessons, observation plans, post-lesson interviews or surveys, case students, reflection meetings or post lesson debriefings, knowledgeable others or LS facilitators, LS reports or dissemination, and public research lessons. While reports and public research lessons are less frequently observed components in Dutch LS, collaborative planning, plans for research lessons, observation plans, post-lesson interviews or surveys, case students, reflection meetings or post lesson debriefings are the most prominent ones in terms of frequency of use according to data collected during the first LS4VET project phase (Mewald et al., 2021).

Dutch LS teams usually plan research lessons for one to more than three hours: Most frequently, three planning meetings last for about one and a half hours each. Each study usually encompasses two cycles carried out within one academic year. A total LS-cycle encompasses approximately 20 hours per teacher; each cycle

${ }^{7}$ https://lessonstudynl.online/ 
usually takes seven meetings. Dutch LS is most common in primary, lower, and upper secondary general education, where LS is quite regularly implemented. When it comes to VET schools and tertiary education, LS is less commonly seen in the Netherlands.

Generally, the goal for Dutch teachers to engage in LS is team building rather than research. Teachers primarily want to improve their teaching and their pupils' learning quality (focus on the own classroom) and to learn from other teachers in a professional learning community (focus on collaboration with other teachers). To research effective methods for teaching in particular topics (focus on content) is a less frequent goal for Dutch teachers.

Student participation plays an important role in Dutch Lesson Study. While younger learners (6-12 years) are mainly involved in LS through giving feedback about learning during and after research lessons, 13-19-year-old Dutch students are not only very actively involved in LS through their feedback, but they sometimes may also play an active role in planning or reflection meetings.

LS does not receive national funding in the Netherlands, but sometimes school funding is provided. If LS is part of in-service training, teachers' participation can improve their professional status. Thus, LS is mainly focused on teachers' professional learning and sometimes accompanied with formal benefits such as national registers where teachers can file their professional development activities.

The typical role of school principals or other school leaders (e.g., subject department heads) lies in initiating, stimulating, motivating, and facilitating LS, but they do not participate actively in the studies. LS in Dutch VET has been carried out in the Netherlands approximately since 2016. It shows the same features as in secondary and primary education, i.e., it currently follows the national model. In addition to the previously mentioned components, its focus is on the vocational context: This means that $a$ class is often interpreted in a broader way - it can also be a workplace situation where vocational education takes place.

In VET, LS teams usually plan research lessons like other LS contexts: There are three meetings lasting between one to one and a half hours each within two cycles. VET teachers pursue mostly similar goals to other contexts: They are interested in their professional learning and in better insight into the learning of students. VET specific goals are to exchange knowledge and skills between more theoretical teachers and practice teachers. For example, a math teacher and an instructor might collaborate to get to know each other's learning practice better.

The institutional benefits, incentives, or obligations for VET teachers to engage in LS are mostly similar to general education contexts: Participation in LS is part of in-service training. In Holland, VET teachers are provided with a particular set of hours for professionalisation which they can use to engage in LS. VET teachers are content with the fact that they have a certain set of hours just to focus on education quality.

Dutch LS teams in VET comprise approximately four teachers. A team may be a group of VET teachers who all teach the same subject such as nursing teachers who all teach anatomy. Teams can be homogeneous (e.g., all math teachers) or heterogeneous (e.g., math and language teachers, or math and theme-based teachers) groups.

The goals of VET teachers to engage in LS are (individual) professionalisation, improving the quality of education, carrying out the vision of the department, team building, and building knowledge about collaboration as well as pupils' learning.

Challenges of LS in VET are scheduling, the scarce availability of classrooms to hold meetings, getting teachers from different teams together, arranging meetings for several teachers at the same time, including work practice teachers, or getting teachers, teams and managers engaged.

Important research questions in LS in VET education are student engagement, connecting in-school and out-ofschool (workplace)learning, social skills development, collaboration, and didactics. The types of lessons being researched in LS in VET education are practical as well as theory lessons, normal lessons, in a theory class or in a practice class. Developments to implement LS in vocational colleges or high schools in the Netherlands encompass bringing together VET LS teams with teacher students and teachers. With LS still in the beginning stage in the Netherlands, the following research questions arise:

- How does LS relate to workplace learning and the hybrid professional?

- What is the role of the manager (and the school leader) in LS?

- How can difficulties in scheduling be overcome?

- How can teachers' training budgets be used effectively for LS?

- How can Practoraten (professorship for VET) act as accelerators in LS? 


\section{Approaches and national models to LS in the LS4VET partner countries}

In Austria, there are official approaches to implement LS at the university colleges of teacher education in Carinthia and in Lower Austria. Moreover, there is a project implementing LS in continuous professional development in Lower Austria called Lernen mit Wissenspartnern und Lesson Study. Apart from the two groups in federal states, there is no unified national group. The Lower Austrian LS-group has published their model on the insitutional LS website and in a handbook (Mewald \& Rauscher, 2019). This model is similar to the model published by Dudley (2019) and the Lesson Study UK group in that it also concentrates on student learning through observing case students. According to the LS group in Lower Austria, a strong reason for preferring LS to other forms collaborative action research is its emphasis on learner participation and the clear focus on learning through concentrating on observation and interviews with the already mentioned case study pupils.

In Hungary, a model for LS based on the original Japanese approach is in a development stage and within the framework of mostly university-based pre- and in-service teacher training programmes.

In Malta, a model for LS is currently in development. It is based on an official approach and within the framework of an institutional group at the University of Malta called CLeStuM.

In the Netherlands, there is a national approach to carry out LS published by the National Consortium LSNL. This body suggests a model for LS which is also published on their website.

In Austria and in the Netherlands, LSs encompass pre-study research, collaborative planning, plans for research lessons, observation plans, post-lesson interviews or surveys, case students, reflection meetings or post lesson debriefings, knowledgeable others or LS facilitators, and LS reports or dissemination in varying degrees. In Hungary, post-lesson interviews, surveys, or case students are not included in LS while Maltese LS does not include public research lessons although the other components are mentioned.

LS has a history of about ten years in Austria, Malta, and the Netherlands. In Hungary, LS is considered in the beginning phase. LS is implemented at all educational levels in Austria and in the Netherlands, although with varying degrees. In Hungary, LS is currently not implemented at upper secondary and tertiary level, and it is not used at tertiary level or at VET schools in Malta. On average, LS teams plan research lessons within 2.4 hours and a LS encompasses 1.8 cycles with an overall duration of the whole study lasting for eleven weeks.

The main goals of teachers who participate in LS are in improving teaching and learning as well as continuous professional development (CPD) in collaborative groups in all four countries. However, LS participants also focus on developing in content areas, research, or qualification in addition to their most prominent goals.

The survey suggests varying degrees of learner participation in LS according to age. However, students seem to be most frequently actively involved as learners and through providing feedback about their learning during or after research lessons.

The target age group of VET learners are actively involved in all parts of the LS in Austria and in the Netherlands. According to our survey, schools may receive direct funding in the Netherlands and LS is part of funded CPD in Austria. Incentives to participate in LS may be the acquisition of ECTS credit points in Austria and Malta. In the Netherlands, gaining status may create motivation to participate in LS. School leaders play an organisational role in LS although they may also participate in Austrian and Maltese LSs.

Overall, LS in VET is in a developmental phase, although there are some schools with experience in Austria, Malta, and the Netherlands. The overall frequency of LSs in VET school is 1.7 per year and VET-LS teams are usually mixed teams of subject and practice teachers in the three countries. Recent developments aim at the implementation of LS in VET in all countries, Austria is also in the process of adding LS to VET teacher education curricula.

The development of a LS model for VET, as propagated in the ERAMSUS+ project LS4VET, thus creates a theoretical foundation and it increases opportunities for VET educators in Europe and beyond to engage in LS and thus create collaborative professionalism within the field in the future.

\footnotetext{
${ }^{8}$ https://www.ph-noe.ac.at/de/fortbildung/spezifische-bereiche/lernen-mit-wissenspartnern-und-lesson-study
} 
R\&E-SOURCE $h$ ttps://journal.ph-noe.ac.at Online Journal for Research and Education

Ausgabe 16, Oktober 2021, ISSN: 2313-1640

\section{References}

Ainley, J., \& Carstens, R. (2018). Teaching and Learning International Survey (TALIS) 2018 Conceptual Framework. https://www.oecd-ilibrary.org/docserver/799337c2en.pdf?expires $=1587055773 \&$ id=id\&accname $=$ guest $\&$ check sum=E5C065F814D9E8D5A303ACF7B455B55B

Bencze R. (2018). Új utak a közoktatásban és a tanárképzésben: A lesson study mint módszertani lehetőség. [New paths in public education and teacher training: Lesson study as a methodological option]. In Kerülö J. \& Jenei T. (Eds.), Pedagógusképzés és az inklúzió: Új kutatások a neveléstudományokban 2017. Debrecen, Kreatív Help.

BMBWF (n.d.). Das österreichische Schulsystem [The Austrian system of education]. https://www.bmbwf.gv.at/Themen/schule/schulsystem.html

BMBWF (2020). Educational Paths in Austria 2020/21. Federal Ministry of Education, Science and Research. https://pubshop.bmbwf.gv.at/index.php?article id=9\&type=neuerscheinungen\&pub=882

BMDW (2020). Apprenticeship System. The Dual System of Vocational Education and Training in Austria. Federal Ministry for Digital and Economic Affairs. Retrieved August 2, 2021, from https://www.bmdw.gv.at/en/Topics/Vocational-Training-and-Skills.html

Bolam, R., McMoahon, A., Stoll, L., Thomas, S., and Wallace, M. (2005). Creating and Sustaining Professional Learning Communities. University of Bristol. https://dera.ioe.ac.uk/5622/1/RR637.pdf

Bruges Communiqué (2010). The Bruges Communiqué on enhanced European Cooperation in Vocational Education and Training for the period 2011-2020. European Ministers for Vocational Education and Training, the European Social Partners and the European Commission, Bruges.

Bükki, E. (2018). Mesterpedagógus szakmai tanárok szakmai életútjai [Professional life paths of 'master' VET teachers]. Educatio. 27(3), 498-507. http://doi.org/10.1556/2063.27.2018.3.1

Bükki, E. (2019). Vocational education and training in Europe: Hungary. Cedefop ReferNet VET in Europe reports 2018.

https://cumulus.cedefop.europa.eu/files/vetelib/2019/Vocational_Education Training_Europe Hung ary 2018 Cedefop ReferNet.pdf

Bükki E., \& Fehérvári A. (2021). How do teachers collaborate in Hungarian VET schools? A quantitative study of forms, perceptions of impact and related individual and organisational factors. Empirical Research of Vocational Education and Training 13(1). https://doi.org/10.1186/s40461-020-00108-6

Bükki, E., \& Győri, J. (2021). IO1-A3 Final Report. Identifying Relevant VET-Specific Factors. Interview Analysis. Budapest: Eötvös Loránd University. https://ls4vet.itstudy.hu/sites/default/files/202107/IO1 A3 LS4VET final report Identifying relevant VET-specific factors 09062021.pdf

Calleja, J., Buhagiar, M., Tonna, M. T. \& Camilleri, T. (2021). Identifying needs for pedagogical change. Online survey analysis. IO1-A4 final Report. University of Malta.

CEDEFOP (2015). 2015 Annual Report. Publications Office of the European Union. Retrieved from https://www.cedefop.europa.eu/files/4145 en.pdf

Czók B. \& Győri J. (2015). Helyzetkép a tanórakutatás (lesson study) magyarországi adaptálásáról/alkalmazásáról [The state of art of the adaptation of lesson study in Hungary]. Presentation on Országos Neveléstudományi Konferencia, 19/November/2015, Óbudai Egyetem, Budapest.

Dornmayr, H., \& Nowak, S. (2020). Lehrlingsausbildung im Überblick 2020. Strukturdaten, Trends und Perspektiven [An overview of apprenticeship training 2020: Data on structure, trends and perspectives]. ibw.

Dudley, P. (2012). Lesson Study development in England: From school networks to national policy. International Journal for Lesson and Learning Studies(1), 85-100.

Dudley, P. (Ed.). (2015). Lesson Study: Professional Learning for Our Time. Routledge.

Dudley, P. (2019). Lesson Study: a handbook. Retrieved from lessonstudy.co.uk: http://lessonstudy.co.uk/lesson-study-a-handbook/

Fehérvári, A. (2014). A szakmai képzés és társadalmi átalakulás [VET and social transformation]. Új Mandátum Könyvkiadó, Budapest. https://issuu.com/emesekarsai/docs/fehervari szakmkepzes

Gordon Györi, J. (2007a). The importance of socio-cultural milieu in implementing lesson study method. Presentation on $1^{\text {st }}$ World Association of Lesson Studies Conference, 28/November/2007. Hong Kong. Retrieved from https://www.walsnet.org/2007/post1.htm 14/August/2021. 
Gordon Győri J. (2007b). Tanórakutatás (Lesson study): Egy elterjedőben lévő oktatásfejlesztési módszer magyarországi adaptációjának kérdései [Lesson study: On the adaptation of a widespread educational development method in Hungary]. Új Pedagógiai Szemle, 57(2), 15-23.

Gordon Győri J. (2009). Tanórakutatás [Lesson study]. Gondolat.

Hargreaves, A., \& Fullan. (2012). Professional capital: Transforming teaching in every school. Routledge.

Hargreaves, A., \& O'Connor, M. T. (2018). Collaborative Professionalism: When Teaching Together Means Learning For All. Corwin Press.

Hermann, Z., Horn, D., Tordai, D. (2020). The effect of the 2013 vocational education reform on student achievement. In: The Hungarian Labour Market 2019. Institute of Economics, Centre for Economic and Regional Studies, pp 64-69. https://kti.krtk.hu/wp-content/uploads/2020/07/LMYB2019 onefile.pdf

Hoeckel, K. (2010). A Learning for Jobs Review of Austria. OECD Reviews of Vocational Education and Training. OECD.

Információs és Technológiai Minisztérium (2018). Szakképzés 4.0: A szakképzés és felnőttképzés megújításának középtávú szakmapolitikai stratégiája, a szakképzési rendszer válasza a negyedik ipari forradalom kihívásaira [Vocational training 4.0: The medium-term vocational policy strategy for the renewal of vocational education and training, the response of the vocational education system to the challenges of the fourth industrial revolution]. Budapest.

https://www.nive.hu/index.php?option=com content\&view=article\&id=1024:szakkepzes-40strategia\&catid=10:hirek\&ltemid=166

Larssen, D.L.S., Cajkler, W., Fauskanger, J., Wood, P., Jakobsen, A., Bugge, H.E., Næsheim-Bjørkvik, G., \& Norton, J. (2018). A literature review of lesson study in initial teacher education. International Journal of Lesson and Learning Studies, 7(1), 8-22.

Leana, C. R. (2011). The Missing Link in School Reform. Stanford Social Innovation Review, Fall 2011. https://ssir.org/images/articles/Missing_Link_Cover.pdf

Lewis, C., \& Hurd, J. (2011). Lesson Study. Heinemann.

Lewis, C., \& Tsuchida, I. (1998). A lesson is like a swiftly flowing river: Research lessons and the improvement of Japanese education. American Educator, 14-17 \& 50-52.

Markowitsch, J., \& Helfer, G. (2019). Future developments in Vocational Education and Training in Europe. Report on reskilling and upskilling through formal and vocational education training. Seville: European Union. Retrieved from https://ec.europa.eu/jrc/en/publication/eur-scientific-and-technical-researchreports/future-developments-vocational-education-and-training-europe

Mewald, C. (2020). Die Rollen von Wissenspartnern in der Lesson Study. In A. Habicher, T. Kosler, C. Lechner, C. Oberhauser, A. Oberrauch, M. Tursky-Philadelphy, ... A. Schuster (Eds.), Tagungsband zur VII. CARN D.A.CH-Tagung (pp. 281-295). Praesens.

Mewald, C., Mar W.Y., Győri, J., Erhard, F., \& Tscherne, M. (2021). Analyzing Lesson Study Experiences Focusing on VET. IO1-A2 Final Report. Retrieved from https://www.ph-

noe.ac.at/fileadmin/root_phnoe/MitarbeiterInnen/IO1_A2_LS4VET_Literature_review_country_partn er_survey_04262021.pdf

Mewald, C., \& Rauscher, E. (Eds.). (2019). Lesson Study: Das Handbuch für kollaborative Unterrichtsentwicklung und Lernforschung. StudienVerlag.

MFED (2014a). Framework for the Education Strategy for Malta 2014-2024: Sustaining Foundations, Creating Alternatives, Increasing Employability. Malta: Ministry for Education.

MFED (2014b). A Strategic Plan for the Prevention of Early School Leaving in Malta. Malta: Ministry for Education. MFED (2015). National Vocational Education and Training Policy. Malta: Ministry for Education.

Mohr, M. (2021). Lehrlingsquote in Österreich bis 2020. Retrieved from https://de.statista.com/statistik/daten/studie/826886/umfrage/lehrlingsquote-in-oesterreich/

PH NÖ (2021a). Bachelorstudium Sekundarstufe/Berufsbildung. Pädagogische Hochschule Baden. Retrieved from https://www.ph-noe.ac.at/de/ausbildung/sekundarstufe-berufsbildung/bachelorstudiumsekundarstufe-berufsbildung

PH NÖ (2021b). Masterstudium Sekundarstufe/Berufsbildung. Pädagogische Hochschule Baden. Retrieved from https://www.ph-noe.ac.at/de/ausbildung/sekundarstufe-berufsbildung/masterstudiumsekundarstufe-berufsbildung

Schleicher, A. (2020). TALIS 2018. Insights and Interpretations. OECD. http://www.oecd.org/education/talis/TALIS2018 insights and interpretations.pdf

Skott, C. K., \& Møller, H. (2020). Adaptation of lesson study in a Danish context: Displacements of teachers' work and power relations. Teaching and Teacher Education, 87, 1-10. 
R\&E-SOURCE $h$ ttps://journal.ph-noe.ac.at Online Journal for Research and Education

Stigler, J. W., \& Hiebert, J. (1999). The teaching gap: Best ideas from the world's teachers for improving education in the classroom. New York: Summit Books.

Takahashi, A. (2013). The Role of the Knowledgeable Other in Lesson Study. Mathematics Teacher Education and Development, 1-16. Retrieved from https://files.eric.ed.gov/fulltext/EJ1046714.pdf

WKO NÖ (2021). Das Fundament für die "Duale Akademie" in Niederösterreich wurde gelegt [The foundation for the "Dual Academy" in Lower Austria was laid]. Niederösterreichische Wirtschaft, 28-30.

Wood, P., Larssen, D.L., Helgevold, N. \& Cajkler, W. (Eds.) (2019). Lesson study in initial teacher education: Principles and practices. Emerald. 


\section{Appendix 1}

\section{PROJECT DATA}

Title: Teachers' Collaboration through Lesson Study for Improving the Quality of Vocational Education and Training

Acronym: LS4VET

Project ID: 2020-1-HU01-KA202-078848

Program: Erasmus+ KA2

Project Type: Strategic Partnership

Target group: teachers and trainers working in VET schools

Secondary target group: teacher educators and student teachers

Beneficiaries: VET students

Participant countries: Austria, Hungary, Malta, Netherlands

Project start: 1 September 2020

Project end: 31 August 2023

Website: https://Is4vet.itstudy.hu

\section{PROJECT PARTNERS}

ELTE Eötvös Loránd University Institute of Intercultural Psychology and Education (Hungary) - project coordinator

iTStudy Hungary Educational and Research Centre Ltd. (Hungary)

Neumann János Computer Science Technical School (Hungary)

Pädagogische Hochschule Niederösterreich \& HTL Wiener Neustadt (Austria)

Universita ta Malta (Malta)

Institute of Tourism Studies (Malta)

University of Applied Sciences Utrecht (Netherland)

Stichting Landstede (Netherland) 


\section{Appendix 2}

\begin{tabular}{|l|l|l|l|l|l|l|}
\hline Source & Phase 1 & Phase 2 & Phase 3 & Phase 4 & $\begin{array}{l}\text { Pupil } \\
\text { feedback }\end{array}$ & Support \\
\hline $\begin{array}{l}\text { Lesson Study } \\
\text { Alliance } \\
\text { (Chicago) }\end{array}$ & $\begin{array}{l}\text { Clear research } \\
\text { purpose } \\
\text { Kyouzai } \\
\text { kenkyuu }\end{array}$ & $\begin{array}{l}\text { written lesson } \\
\text { research } \\
\text { proposal with } \\
\text { unit plan }\end{array}$ & $\begin{array}{l}\text { live research } \\
\text { lesson and } \\
\text { post-lesson } \\
\text { discussion }\end{array}$ & $\begin{array}{l}\text { Contribution } \\
\text { by } \\
\text { knowledge- } \\
\text { able others } \\
\text { process for } \\
\text { sharing } \\
\text { results }\end{array}$ & $\begin{array}{l}\text { LessonNote } \\
\text { App }\end{array}$ \\
\hline $\begin{array}{l}\text { Lesson Study UK } \\
\text { (Dudley, 2019) }\end{array}$ & planning of RL & $\begin{array}{l}\text { teach and } \\
\text { observe } \\
\text { and revision } \\
\text { of RL }\end{array}$ & interviews & interviews & $\begin{array}{l}\text { 'moderator' } \\
\text { discussion; } \\
\text { 'adviser' - final } \\
\text { commentator }\end{array}$ \\
\hline $\begin{array}{l}\text { Lewis and Hurd } \\
\text { (2011) }\end{array}$ & study & plan & do & knowledge \\
\hline $\begin{array}{l}\text { Mills College } \\
\text { able outsider }\end{array}$
\end{tabular}

Table 1: Selected LS models in Europe and the US

Lesson Study Alliance (Chicago)

https://www.Isalliance.org/

Lesson Study UK

https://lessonstudy.co.uk/

Mills College

https://lessonresearch.net/

SCITT Lesson Study

http://scittls.weebly.com/

Teacher Development Trust Network

https://tdtrust.org/lessonstudy/?utm source=adwords\&utm term=teacher\%20development\%20trust\&utm c ampaign=TDT+Network+New\&utm medium $=$ ppc\&hsa $\mathrm{src}=\mathrm{g} \& \mathrm{hsa}$ ad $=172836126690 \& \mathrm{hsa}$ acc $=8691751010$ \& hsa grp=44273315211\&hsa kw=teacher\%20development\%20trust\&hsa tgt=kwd278165277770\&hsa net=adwords\&hsa ver=3\&hsa mt=b\&hsa cam=738286942\&gclid=CjOKCQjwsZKJBhCOARI sAJ96n3X0n3gVe1C8ecmsKxIxMn-OX-3VxUfTGzc5j64gTSFWip SAqx8M8kaAt4zEALw wcB

Texas Lesson Study

https://www.texasgateway.org/lesson-study 
R\&E-SOURCE https://journal.ph-noe.ac.at

Online Journal for Research and Education

Ausgabe 16, Oktober 2021, ISSN: 2313-1640

SOURCE

\section{Appendix 3}

\begin{tabular}{|l|l|l|l|l|l|l|}
\hline Source & Phase 1 & Phase 2 & Phase 3 & Phase 4 & $\begin{array}{l}\text { Pupil } \\
\text { feedback }\end{array}$ & Support \\
\hline $\begin{array}{l}\text { Lesson Study } \\
\text { (Mustria } \\
\text { Rauscher, } \\
\text { 2019) }\end{array}$ & $\begin{array}{l}\text { Pre-study } \\
\text { research \& } \\
\text { collaborative } \\
\text { planning of } \\
\text { research } \\
\text { lesson }\end{array}$ & $\begin{array}{l}\text { Implementation } \\
\text { and observation } \\
\text { of research } \\
\text { lesson }\end{array}$ & $\begin{array}{l}\text { post-lesson } \\
\text { interviews/ } \\
\text { surveys }\end{array}$ & $\begin{array}{l}\text { reflection } \\
\text { meeting/ } \\
\text { post lesson } \\
\text { debriefing \& } \\
\text { report }\end{array}$ & interviews & $\begin{array}{l}\text { knowledgeable } \\
\text { others } \\
\text { LS facilitators }\end{array}$ \\
\hline $\begin{array}{l}\text { Lesson Study } \\
\text { Malta } \\
\text { CLeStuM }\end{array}$ & $\begin{array}{l}\text { Kyouzai } \\
\text { kenkyuu \& } \\
\text { research } \\
\text { lesson } \\
\text { design }\end{array}$ & $\begin{array}{l}\text { live research } \\
\text { lesson }\end{array}$ & $\begin{array}{l}\text { post-lesson } \\
\text { discussion }\end{array}$ & $\begin{array}{l}\text { summary \& } \\
\text { next steps }\end{array}$ & & \\
\hline $\begin{array}{l}\text { Lesson Study } \\
\text { in the } \\
\text { Netherlands } \\
\text { Dutch LS } \\
\text { Model }\end{array}$ & $\begin{array}{l}\text { theme and } \\
\text { goal }\end{array}$ & $\begin{array}{l}\text { research lesson } \\
\text { design }\end{array}$ & $\begin{array}{l}\text { implementation, } \\
\text { observation, } \\
\text { interviews, } \\
\text { surveys etc. }\end{array}$ & $\begin{array}{l}\text { discussion, } \\
\text { analysis and } \\
\text { revision }\end{array}$ & $\begin{array}{l}\text { interviews, } \\
\text { surveys etc. }\end{array}$ & LS facilitators \\
\hline
\end{tabular}

Table 2: LS models in Austria, Malta, and the Netherlands

Lesson Study Austria

https://www.ph-noe.ac.at/de/lessonstudy

Lesson Study Malta

https://www.clestum.eu/

Lesson Study Netherlands

https://lessonstudynl.online/ 


\section{Appendix 4}

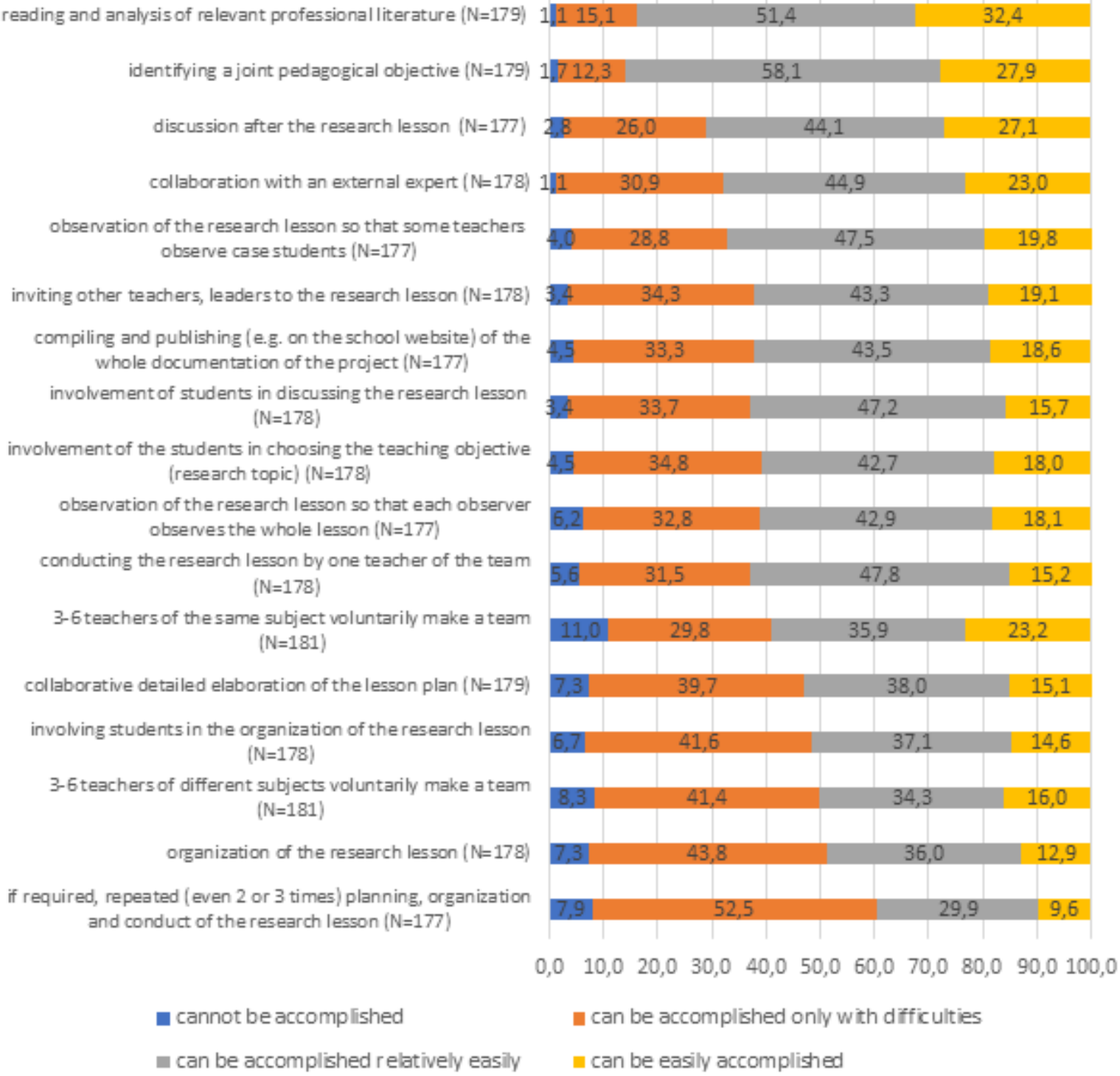

observation of the research lesson so that each observer observes the whole lesson ( $\mathrm{N}=177)$

conducting the research lesson by one teacher of the team $(\mathrm{N}=178)$

3-6teachers of the same subject voluntarily make a team $(\mathrm{N}=181)$

collaborative detailed elaboration of the lesson plan $(\mathrm{N}=179$ involving students in the organization of the research lesson $(\mathrm{N}=178)$

3-6teachers of different subjects voluntarily make a team $(\mathrm{N}=181)$

organization of the research lesson ( $N=178$ )

if required, repeated (even 2 or 3 times) planning, organization and conduct of the research lesson $(\mathrm{N}=177)$

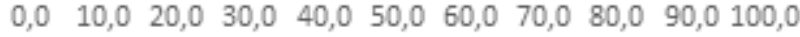

a cannot be accomplished

can be accomplished only with difficulties

a can be accomplished relatively easily

Question asked: How easy or difficult would it be in your opinion to implement a Lesson Study in your school?

Figure 1: VET teachers' opinion about the feasibility of various LS components in the Hungarian nationwide survey (\%) 